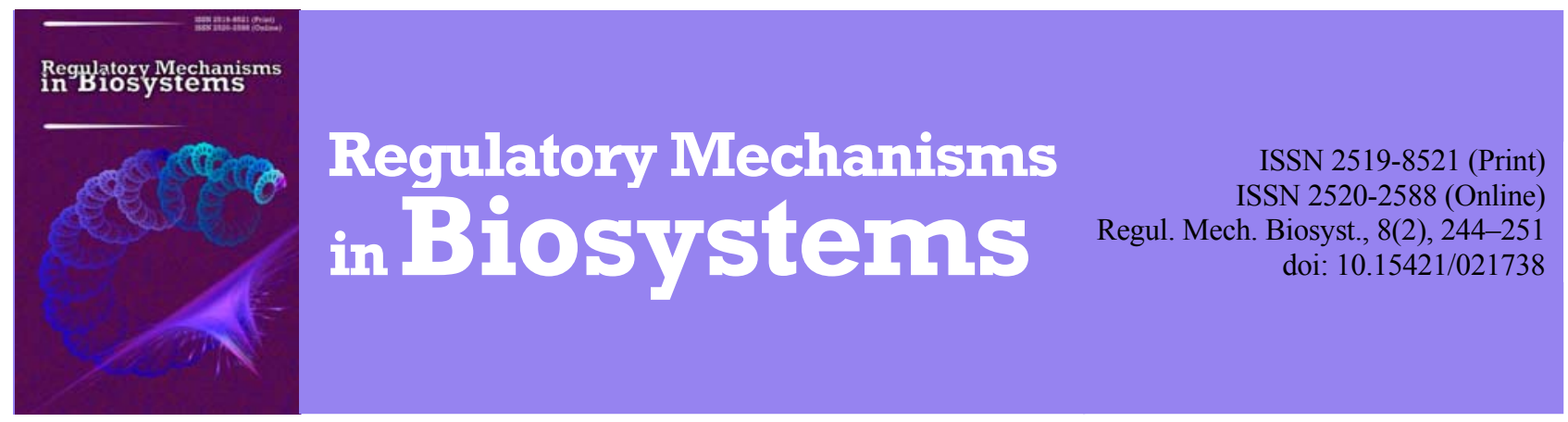

\title{
Analysis of brain bioelectric activity during verbal-logical thinking of biology students
}

\author{
T. O. Tretiak, A. G. Sokorenko, I. V. Dregval, O. V. Severynovska \\ Oles Honchar Dnipro National University, Dnipro, Ukraine
}

Article info

Received 24.03.2017

Received in revised form 20.04.2017

Accepted 23.04.2017

Oles Honchar Dipro National University, Gagarin Ave., 72

Dnipro, 49010, Ukraine

Tel.: +38-050-232-77-38.

E-mail:

drehval_iho@fbem.dnulive.dp.ua

Tretiak, T. O., Sokorenko, A. G., Dregval, I. V., \& Severynovska, O. V. (2017). Analysis of brain bioelectric activity during verbal-logical thinking of biology students. Regulatory Mechanisms in Biosystems, 8(2), $244-251$. doi:10.15421/021738

75 female students of biology aged 18-22 were examined. The indicators of coherence of frequency components of electroencephalography in a quiet state and during solving tasks, involving verbal-logical type of thinking, were assessed. The study included two stages: at the first stage, the individual psycho-physiological features of the students were investigated, then, the students investigated were divided into two groups, those with low and those with medium levels of performing tests. Performance of tasks involving verbal-logical thinking, compared with the background state, was characterized by polyrhythmic EEG activity with dominating $\delta$-oscillations and prevailing $\delta$-activity in the frontal area, which indicates their special role in regulation of complicated forms of cognitive activity. With development of ability of verbal-logical thinking, we established the increase in the spectral capacity in the frontal $\mathrm{F}_{3}, \mathrm{~F}_{7}, \mathrm{central}_{3}, \mathrm{C}_{4}$, parietal $\mathrm{P}_{3}, \mathrm{P}_{4}$ and temporal $\mathrm{T}_{5}$ leads and increasing of synchronization in $\alpha$-range in the left frontal zone, in areas near the Vernike zone and in the contour area $\mathrm{F}_{4}-\mathrm{F}_{8}-\mathrm{T}_{4}-\mathrm{P}_{4}$ of the right hemisphere. In the process of solving logical problems, the students with the low level of development of this cognitive ability demonstrated an increase of SC of $\beta_{1^{-}}$ oscillation in $\mathrm{Fp}_{2}, \mathrm{P}_{3}, \mathrm{O}_{2}$ leads, and the students with the medium level of development of logical thinking, on the contrary, demonstrated a reliable decrease in capacity of $\beta_{1}$-oscillations in the central $\mathrm{C}_{4}$ and parietal $\mathrm{P}_{4}$ leads. However, in the most productive students, a considerable number of significant functional connections and high values of coefficients of coherence between frontal $\mathrm{F}_{3}-\mathrm{F}_{4}, \mathrm{~F}_{4}-\mathrm{C}_{4}$, central and parietal $\mathrm{C}_{3}-\mathrm{P}_{3}, \mathrm{C}_{4}-\mathrm{P}_{3}, \mathrm{C}_{4}-\mathrm{P}_{4}$ and occipital $\mathrm{O}_{1}-\mathrm{O}_{2}$ leads in the above mentioned EEG range were recorded. The spectral capacity of $\beta_{2}$-components of EEG in students with different levels of development of logical thinking varied within background values and decreased in certain sections. The students with the medium level of manifestation of verbal-logical thinking demonstrated synchronization of SC of $\beta_{2}$-range between frontal $\mathrm{Fp}_{1}-\mathrm{Fp}_{2}, \mathrm{Fp}_{2}-\mathrm{F}_{7}, \mathrm{~F}_{3}-\mathrm{F}_{4}$ and other $\mathrm{C}_{3}-\mathrm{C}_{4}, \mathrm{O}_{1}-\mathrm{T}_{5}, \mathrm{~T}_{3}-\mathrm{T}_{4}$ leads. While performing the tasks involving logical thinking, the students with low manifestation of this mental ability, did not demonstrate any considerable changes in indicators of SC of the $\theta$-range. However, a reliable increase was established in the $\mathrm{Fp}_{1}, \mathrm{Fp}_{2}, \mathrm{~F}_{7}$ and in $\mathrm{O}_{2}$ leads in the students tested in the group with the medium manifestation of cognitive ability. It should also be noted that with the development of verbal-logical way of thinking, the brain transfers in a special functioning mode with the low functional connection in the area of $\theta$-oscillations, which indicates the preservation of the previously formed neural network. Therefore, in this work, we for the first-time distinguished special features and functional connections during performing verbal, rather than mathematical cognitive logical tasks: localization of loci of interaction at $\alpha$ frequencies in frontal and central leads of the right hemisphere; $\beta_{1}-$ in frontal leads of the left and central right hemisphere, $\beta_{2}$ - in frontal and occipital left and in occipital areas of the right hemisphere. It was established that in lowfrequency $\delta$ - and $\theta$-ranges of EEG, both large cell ensembles, which embrace almost all right hemisphere, and separate sections in frontal, pariental, pariental-occipital locuses of the left hemisphere, are functionally integrated.

Keywords: spectral capacity of EEG; verbal-logical type of thinking; cognitive ability

\section{Аналіз біоелектричної активності мозку у процесі словесно-логічного мислення студентів-біологів}

\author{
Т. О. Третяк, А. Г. Сокоренко, І. В. Дрегваль, О. В. Севериновська
}

Дніпровський національний університет імені Олеся Гончара, Дніпро, Украӥна

У 75 студенток-біологів віком 18-22 роки досліджували спектральну потужність і оцінювали показники когерентності частотних компонентів ЕЕГ у стані спокою та під час вирішення завдань на словесно-логічний тип мислення. Попередньо, за результатами комплексного дослідження визначились із категорією досліджуваних осіб: амбіверти, холерично-сангвінічного типу темпераменту, 3 помірним рівнем тривожності та високим рівнем стресостійкості, праворукі, або правші, з відсутністю астенії, яких за розвитком мислення 
поділили на групи з низьким і середнім проявом словесно-логічного типу мислення. Із розвитком здібності до когнітивного мислення збільшується домінування $\delta$-осциляцій та кількість когерентних зв'язків спектральної потужності ЕЕГ в області $\delta$-частот, оскільки саме вони формують вхідний сенсорний потік за умов підвищеної уваги. Також відбувалося збільшення спектральної потужності електроенцефалограми в $\alpha$-діапазоні в деяких точках фронтальної, центральної, тім'яної та скроневої областей, переважно лівої гемісфери та посилення синхронізації в у лівій фронтальній і центральній зонах у контурній області $\mathrm{F}_{4}-\mathrm{F}_{8}-\mathrm{T}_{4}-\mathrm{P}_{4}$ правої півкулі. За незначної відмінності від фонових значень спектральної потужності $\beta_{1}$-осциляцій ЕЕГ відмічали посилення функціональних зв'язків та високі значення коефіцієнтів когерентності між фронтальними $\mathrm{F}_{3}-\mathrm{F}_{4}, \mathrm{~F}_{4}-\mathrm{C}_{4}$, центральними й тім'яними $\mathrm{C}_{3}-\mathrm{P}_{3}, \mathrm{C}_{4}-\mathrm{P}_{3}, \mathrm{C}_{4}-\mathrm{P}_{4}$ i потиличними відведеннями. Спектральна потужність $\beta_{2}$-складових ЕЕГ коливалась у межах фонових значень, збільшувалась синхронізація СП $\beta_{2}$-діапазону між передніми та деякими центральними, скроневими та потиличними локусами. У низькочастотних $\delta$ - та $\theta$-діапазонах ЕЕГ функціонально поєднуються як великі клітинні ансамблі правої гемісфери, так і окремі ділянки лівої півкулі.

Ключові слова: спектральна потужність ЕЕГ; словесно-логічний тип мислення; когнітивна здібність

\section{Вступ}

Дослідження процесів мислення шляхом аналізу доступних психофізіологічних показників сучасними комп'ютерними методами, зокрема, вимірювання та аналіз параметрів біоелектричної активності мозку, належить до перспективних напрямів сучасних когнітивних досліджень (Kraft et al., 2009; Klawitter et al., 2010; Sviderskaya, 2011). Ритми - основа ЕЕГ і тісно пов'язані $з$ мозковими функціями, наприклад, з увагою, сприйняттям і запам'ятовуванням (Poch et al., 2014; Freunbergera et al., 2011). Протягом XX століття для аналізу ритмів ЕЕГ пропонували декілька методик, однак функціональне значення багатьох ритмів, особливо тих, які з'являються у процесі когнітивної діяльності людини, досі не з'ясовано. За когнітивної діяльності (виконання вербально-логічних і просторово-образних завдань) на ЕЕГ людини встановлюються ритмічні патерни, які можна однозначно ідентифікувати з характером розумового процесу (Trofimov et al., 2015; Ivanitsky et al., 2010; Roik and Ivanitsky, 2010).

Як відомо, словесно-логічне мислення здійснюється за допомогою логічних операцій із поняттями, в яких суттєві закономірності та взаємозв'язки досліджуваної реальності не наявні. Розвиток словесно-логічного мислення перебудовує та впорядковує світ образних уявлень і практичних дій, тому вивченню цього типу когнітивної діяльності присвячено значну кількість праць (James, 2012; Hyunjeong Lee, 2013; Jashin, 2015; Slavutskaja, 2015).

Ще з класичних праць відомо, що розумова діяльність викликає стійку десинхронізацію $\alpha$-ритму. Також за когнітивної активності відбувається перебудова частотно-амплітудних параметрів $\mathrm{EEГ,} \mathrm{яка} \mathrm{охоплює} \mathrm{всі} \mathrm{основні} \mathrm{частотні} \mathrm{діапазони.} \mathrm{Dzhebrailova}$ et al. (2015) показано, що у продуктивніших студентів на різних етапах виконання завдання на логічне мислення відбувається зміна рівня та структури потенціалів ЕЕГ $\alpha$-діапазону, а в осіб із гіршими результатами кількість значущих когерентних організацій та їх структура не змінюються під час виконання завдань. До того ж, $\alpha$-потужність пов'язана з активацією уваги, хоча, як стверджують Limbach and Corballis (2017), цей зв'язок може бути досить складним. До того ж, динаміка $\alpha$-активності за розумової діяльності має непростий характер: низько- та високочастотний $\alpha$-ритм, що більшою мірою співвідноситься 3 когнітивними аспектами діяльності, тоді як середньочастотний $\alpha$-ритм відображає процеси неспецифічної активації (Sauseng et al., 2015).

Кортикальна активність в $\alpha$-діапазоні ЕЕГ виявилася особливо чутливою до творчості, але іiі функціональне значення в контексті творчого пізнання ще не цілком з'ясоване. Зокрема, збільшення $\alpha$-синхронізації під час творчого мислення у працях Fink et al. (2009) трактується по-різному: як функціональний корелят кортикального відділу на холостому ходу, або, конкретніше, як селективне інгібування зон мозку. ЕЕГ-дослідження цих авторів показало, що генерація оригінальних ідей пов'язана з $\alpha$-синхронізацією в лобових областях мозку та 3 дифузним поширеним візерунком $\alpha$-синхронізації над тім'яною ділянкою кори. МРТ дослідження показало, що виконання завдання супроводжується активацією лобових областей лівої півкулі. Крім того, встановили синхронізацію у тім'яноскроневих ділянках мозку. Отримані дані свідчать, що синхронізація ЕЕГ $\alpha$-діапазону у процесі творчого мислення стає ознакою пізнавальної активації коркових процесів.
За даними низки авторів, когнітивна активність у дорослих супроводжується підвищенням потужності $\beta$-ритму, причому значуще посилення високочастотної активності спостерігається під час розумової діяльності, що включає елементи новизни, у той час як стереотипні, повторювані розумові операції викликають iii зниження (Vol'f and Tarasova, 2010; Dzhebrailova et al., 2013; Dzhebrailova and Korobejnikova, 2013).

Вже не викликає сумніву той факт, що існує зв'язок gammaритму 3 процесами сприйняття, уваги, свідомості та семантичної обробки інформації (Crick and Koch, 1995; Payne, 2002). Амплітуда та частота цього ритму залежать від стану людини та виду когнітивного завдання (Freeman and Barrie, 2000). Саме на частоті gamта-ритму відбувається синхронізація активності та функціональне об'єднання просторово віддалених популяцій нейронів під час здійснення свідомої діяльності (Thürer et al., 2016). Збільшення абсолютної спектральної потужності в gатта-діапазоні спостерігали за зростанням складності когнітивних завдань і реєстрували в лівій півкулі, у лобних і зорових ділянках, а також у правій тім'яно-скроневій області (Simos et al., 2002). Підвищення активності gamma-ритму у процесі зростання складності когнітивних завдань відмічали (Posada et al., 2003), у той час як активність $\beta$-ритму знижувалась (Gross and Gotman, 2009). Makeig and Jung (1996) показали, що gатmа-активність зростає у стані активації, у процесі правильного впізнання зорового стимулу, тоді як під час процесу приняття помилкових рішень і у стані дрімоти gатта-активність зменшується. Можна зробити висновок, що gатmа-активність модулюється у процесі переробки інформації на тлі активації та спрямованої уваги до зовнішніх стимулів.

Незважаючи на численні дослідження, у загальних рисах ми знаємо, що процес мислення являє собою складну аналітико-синтетичну діяльність усієї кори великих півкуль головного мозку, де першочергове значення мають тимчасові зв'язки, які утворюються між аналізаторами та різними відділами кори головного мозку (Gavin et al., 2016). Проте залишається багато невирішених питань стосовно співвідношень параметрів ЕЕГ: спектрального складу змін, екзальтації або депресії ритмів ЕЕГ, картування спеціалізації та міжпівкульної асиметрії відділів кори у процесі словесно-логічного мислення.

Тому мета роботи - вивчити індивідуальні особливості розумової активності студентів-біологів під час виконання певних видів словесно-логічних завдань. Предмет дослідження логічний тип мислення як складова індивідуальних особливостей інтелектуальної діяльності людини.

\section{Матеріал і методи досліджень}

Обстежили 75 студенток-біологів віком 18-22 роки. Усі випробувані дали письмову добровільну згоду на участь у дослідженні та були практично здоровими, без шкідливих звичок. Усі дослідження проведено відповідно до основ біотичних норм Гельсінської декларації Всесвітньої медичної асоціації про етичні принципи науково-методичних досліджень за участі людини (1964-2000), Універсальної декларації з біоетики та прав людини (ООН, 1997), норм Конвенції про захист прав людини у зв'язку із впровадженням нових біомедичних технологій (м. Ов’єдо, Іспанія, 1997), Декларації принципів толерантності (1995), наказу МОЗ України від 13.02.2006 р. № 66. Усі обстежені дали письмову добровільну згоду на участь у до- 
слідженні. Вжито необхідних заходів для забезпечення анонімності обстежуваних.

Дослідження проводили в тихому, добре провітрюваному затемненому приміщенні з постійною температурою $+20 \ldots+22^{\circ} \mathrm{C}$, у ранкові години, що дозволило виключити вплив добових коливань варіабельності серцевого ритму (ВСР) на результати дослідження (Kiselev et al., 2008).

Накладення електродів і реєстрацію електричної активності кори головного мозку проводив сертифікований лікар-діагност Дніпропетровської клінічної лікарні на залізничному транспорті в кабінеті функціональної діагностики. Під час ЕЕГ-експерименту обстежувані перебували у звуко- та світлонепроникній кімнаті у положенні сидячи в кріслі на відстані 1,5 м від монітора комп’ютера. Перед початком дослідження їм давали інструкцію про хід експерименту.

У процесі розумової діяльності здійснювали реєстрацію та первинний аналіз ЕЕГ-активності за допомогою апаратно-програмного комплексу DX-NT32.V19 (виробник «DX-Complex», LTD, м. Харків, Україна). ЕЕГ відводили з поверхні шкіри із застосуванням стандартних методичних прийомів. Активні електроди розміщували за схемою 10-20 у 16 точках на скальпі: використовували лобові $\left(\mathrm{Fp}_{1}, \mathrm{Fp}_{2}, \mathrm{~F}_{3}, \mathrm{~F}_{4}, \mathrm{~F}_{7}, \mathrm{~F}_{8}\right)$, центральні $\left(\mathrm{C}_{3}, \mathrm{C}_{4}\right)$, скроневі $\left(\mathrm{T}_{3}, \mathrm{~T}_{4}, \mathrm{~T}_{5}, \mathrm{~T}_{6}\right)$, тім'яні $\left(\mathrm{P}_{3}, \mathrm{P}_{4}\right)$, потиличні $\left(\mathrm{O}_{1}\right.$, $\mathrm{O}_{2}$ ) відведення. Референтом слугували поєднані електроди $\mathrm{AV}$, які фіксували на мочках вух. Нейтральний електрод розташовувався на ділянці лоба. Кожна піддослідна брала участь у дослідженні двічі: попереднє обстеження на відсутність патологій і власне дослід.

Реєстрували п'ятихвилинні інтервали ЕЕГ. Під час проведення Фур'є-реалізації епоха аналізу складала 500 мс. Частота дискретизації аналогового сигналу становила 2 мс; вхідний опір для синфазного сигналу - понад 100 МОм. Фільтри високих частот установлювали на 50 Гц, низьких - 0,5 Гц. Межі можливої відносної похибки під час вимірювання напруги та часових інтервалів електроенцефалографічних сигналів $- \pm 5 \%$. Видалення ЕЕГ-артефактів проводили експертним методом у режимі перегляду запису, згідно з програмою приладу.

Сумарна тривалість чистого запису варіювала від студентка до студентки. Для того, щоб уникнути впливуцих обставин на параметри ЕЕГ, які у подальшому аналізували, визначили найкоротший «чистий» запис у кожної дослідженої. Таким чином аналізували 4-хвилинний запис, для якого розраховували значення нормованої спектральної потужності та когерентність для симетричних півкулевих та міжпівкулевих пар відведень у частотних смугах, що відповідають $\delta(1-4$ Гц), $\theta$ (4-8), $\alpha(8-13), \beta_{1}(20-30)$ та $\beta_{2}(50-70$ Гц) ритмам.

Дослідження проводили у два етапи: на першому етапі вивчали індивідуальні психофізіологічні особливості студентів. За результатами тестування відбирали однорідні групи для подальшого дослідження. Когнітивні завдання підбирали з числа тих, які використовують практичні психологи, відповідно до особливостей кожної методики (Posner et al., 2007; Klimesch et al., 2010).

Вербально-логічне мислення вивчали за тестом М. Войнаровського (Schroeder and Lakatos, 2009). Цей тест спрямований на визначення здібності до логічного мислення у досліджуваного та визначення формальної правильності того чи іншого логічного умовиводу на основі визначених тверджень (або низки тверджень). Тест не потребує математичних знань. Усі слова потрібно тлумачити так, як це робиться у повсякденній мові. Реальна дійсність не відіграє ніякої ролі (це дещо ускладнює завдання, оскільки зміст деяких тверджень абсурдний, але тест логічно неперевершений).

Після кожного тесту робили перерву на 15 хвилин. Фіксували самопочуття піддослідних.

У кінці дослідження визначали коефіцієнт успішності (продуктивність) виконання завдання у відсотках, відмічаючи та оцінюючи обрані відповіді. Значення до 50\% правильних відповідей вважали низькими, 51-75\% - середніми, а понад 76\% високими. Для подальшого дослідження обрано дві групи під- дослідних із низьким і середнім рівнем продуктивності виконання завдання.

Матеріали досліджень оброблені статистичними методами, із застосуванням аналізу та регресійного моделювання за допомогою статистичних пакетів Statistica 6.0. Використовували методи непараметричної статистики: медіану та інтерактивний розмах. Шляхом математичної обробки на основі алгоритму швидкого перетворення Фур'є розраховували такі кількісні параметри ЕЕГ як інтенсивність електричної активності, що характеризує активацію кори головного мозку в зоні відведення, та величини кроскореляційної функції попарно взятих відведень, які відображають рівень просторової синхронізації. Порівняння вибірок проводили за допомогою критерію знакових рангових сум Вілкоксона.

\section{Результати та їх обговорення}

Попередньо, за результатами комплексного дослідження визначилися з категорією досліджуваних осіб: амбіверти, холерично-сангвіничного типу темпераменту, 3 помірним рівнем тривожності та високим рівнем стресостійкості, праворукі, або правші, з відсутністю астенії, яких за розвитком мислення поділили на групи з низьким і середнім проявом словесно-логічного типу мислення.

Під час розв'язання логічних задач у студентів обох груп у цілому спостерігали зниження спектральної потужності коливань $\alpha$-діапазону в 1,5-3,6 раза порівняно з фоновими значеннями, що відповідає стану «відкриті очі». При цьому у досліджуваних із низьким рівнем розвитку логічного мислення вірогідне зниження потужності $\alpha$-осциляцій виражене майже в усіх ділянках, крім фронтальних відділів. Зафіксовано вірогідне зниження СП у групи студентів із середнім рівнем розвитку логічного мислення в 1,5-2,8 раза в усіх без винятку ділянках мозку, найбільш виражене у точках $\mathrm{F}_{3}, \mathrm{~F}_{4}, \mathrm{P}_{3}, \mathrm{P}_{4}, \mathrm{O}_{1}, \mathrm{O}_{2}, \mathrm{~T}_{5}, \mathrm{~T}_{6}$ (рис. 1).

Пік $\alpha$-ритму позитивно корелює 3 різними когнітивними функціями: увагою, пам'яттю, швидкістю перебігу інформаційних процесів (Klimesch, 1997; Klimesch, 1999; Angelakis et al., 2004). Зниження потужності $\alpha$-ритму під час когнітивного навантаження, наприклад, під час розв'язання арифметичних задач відбувається зниження потужності $\alpha$-ритму внаслідок використання робочої пам'яті, що спричиняє пригнічення $\alpha$-ритму на ЕЕГ.

Результати порівняння (за U-критерієм Манна - Уїтні) значень СП у студенток із різним рівнем розвитку логічного мислення свідчать про вірогідне збільшення СП $\alpha$-хвиль у більш продуктивних осіб у фронтальних $\mathrm{F}_{3}, \mathrm{~F}_{7}$, центральних $\mathrm{C}_{3}, \mathrm{C}_{4}$, тім'яних $\mathrm{P}_{3}, \mathrm{P}_{4}$ та у скроневому $\mathrm{T}_{5}$ відведеннях (рис. 2).

Під час виконання логічних завдань у студентів із низьким рівнем розвитку даної когнітивної здібності відмічається збільшення СП $\beta_{1}$-осциляцій у $\mathrm{Fp}_{2}, \mathrm{P}_{3}, \mathrm{O}_{2}$ відведеннях, а у студентів із середнім рівнем розвитку логічного мислення, навпаки, зниження СП $\beta_{1}$-осциляцій у центральному $\mathrm{C}_{4}$ та тім'яному $\mathrm{P}_{4}$ відведеннях. Спектральна потужність $\beta_{2}$-осциляцій у студентів із різним рівнем розвитку логічного мислення коливається в межах фонових значень і знижується в окремих ділянках. Як вказують Dordzhieva and Pantina (2015), iз розвитком логічного мислення найбільш різноспрямовані зміни спектральної потужності $\beta$-ритму встановлено у фронтальному $\mathrm{F}_{7}$, скроневому $\mathrm{T}_{6}$ i центральних відведеннях. Слід зазначити, що пред'явлені завданя були не складними для студентів, не були пов'язані з розвитком втоми, яка виражалась би у значному посиленні потужності ß-ритму (Kiroj, 2003).

Результати порівняння (за U-критерієм Манна - Уїтні) значень СП $\beta_{1}$-осциляцій у студентів із різним рівнем розвитку логічного мислення свідчать про вірогідне збільшення потужності у фронтальному $\mathrm{F}_{7}$ та потиличних відведеннях. Розвиток логічного способу мислення відбивається і на вірогідному збільшенні СП $\beta_{2}$-коливань у фронтальному відведенні $\mathrm{F}_{7}$ у лівій півкулі мозку, а також $\beta_{2}$-осциляцій - у тім'яному $\mathrm{P}_{3} \mathrm{i}$ скроневих $\mathrm{T}_{3}, \mathrm{~T}_{4}$ відведеннях (рис. 2). 

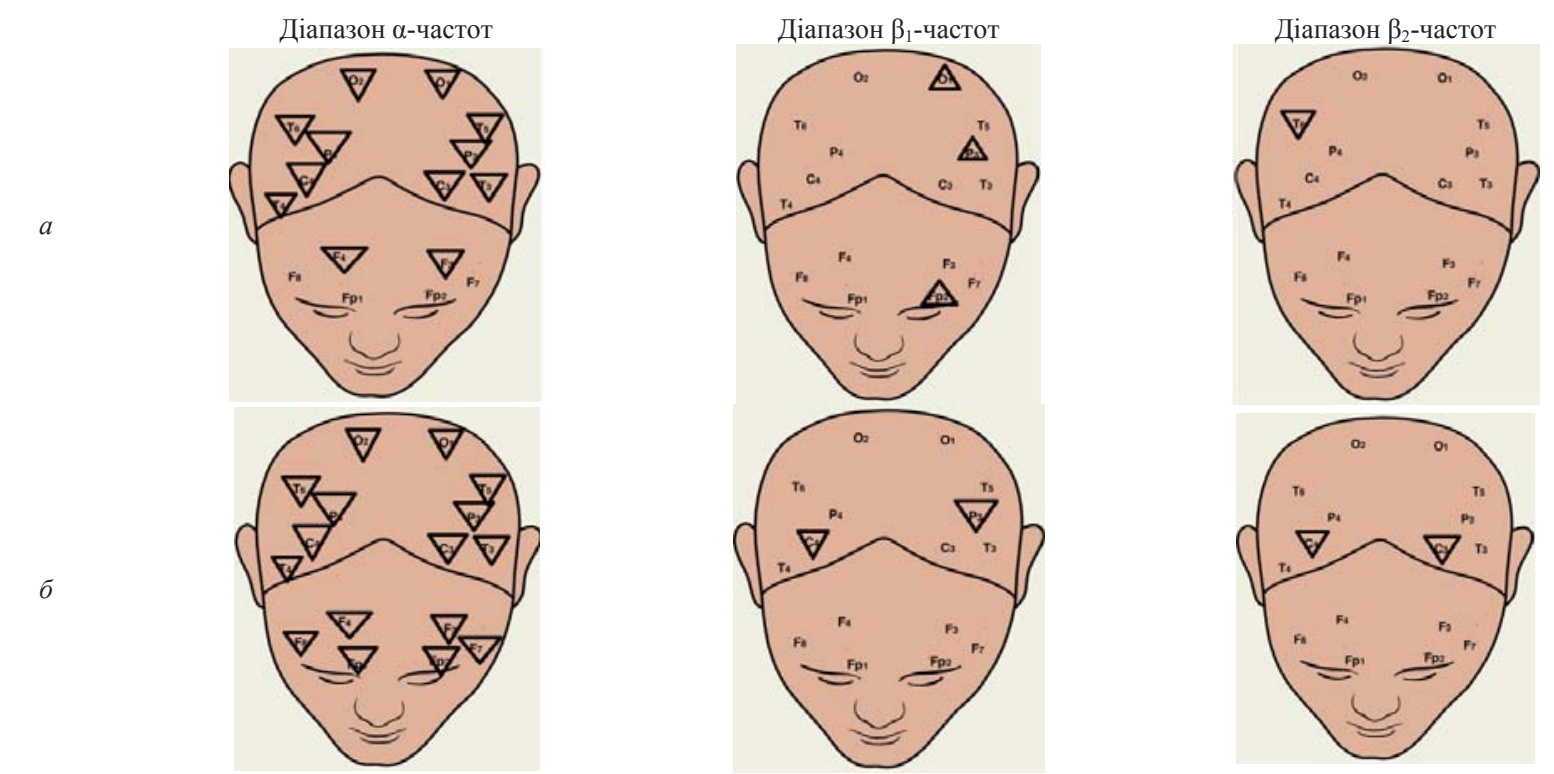

Рис. 1. Зміни показників потужності високочастотних складових ЕЕГ у процесі словесно-логічного мислення у студентів 3 низьким (a) i середнім (б) проявом продуктивності мислення порівняно зі станом спокою із закритими очима; трикутник із вершиною донизу свідчить про зниження, з вершиною доверху - про зростання СП частот $\alpha, \beta_{1}, \beta_{2}$-діапазону, за рівня значимості $\mathrm{P}<0,05$ за критерієм Вілкоксона
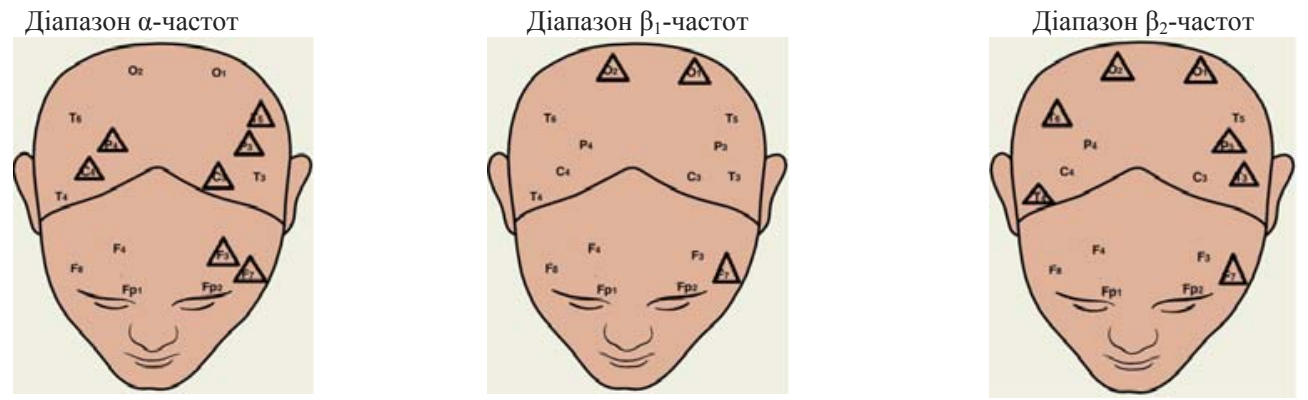

Рис. 2. Ділянки вірогідних змін СП високочастотних складових ЕЕГ у студентів із середнім рівнем прояву словесно-логічного мислення порівняно зі студентами з низькою продуктивністю за рівня значимості $\mathrm{P}<0,05$ за U-критерієм Манна - Уїтні: позначення див. рис. 1

В осіб із низьким рівнем розвитку логічного мислення під час проходження тесту на логіку у біоелектричній активності виявили поліритмічну активність із домінуванням $\delta$-ритму (рис. 3), хоча вірогідне збільшення СП $\delta$-діапазону (відносно фонових значень) відмічали лише у правому потиличному відведенні $\mathrm{O}_{2}$. В осіб із середнім рівнем прояву логіки під час дослідження на логічний тип мислення реєстрували поліритмічний тип біоелектричної активності. Разом із тим у цієї групи досліджених під час виконання завдання встановили збільшення СП $\delta$-осциляцій у фронтальних $\mathrm{Fp}_{1}, \mathrm{Fp}_{2}, \mathrm{~F}_{7}, \mathrm{~F}_{8}$ потиличних та лівій скроневій $\mathrm{T}_{3}$ ділянках кори головного мозку.

Під час виконання завдань на логічне мислення у студентів із низьким проявом цієї розумової здібності значимих змін у показниках СП $\theta$-діапазону не зафіксовано. А в осіб із середнім проявом словесно-логічного мислення вірогідне збільшення встановлене у передніх $\mathrm{Fp}_{1}, \mathrm{Fp}_{2}, \mathrm{~F}_{7}$ й у $\mathrm{O}_{2}$ відведеннях.

Результати порівняння значень СП низькочастотних $\delta$ - та $\theta$-складових у студентів із різним рівнем розвитку логічного мислення свідчать про збільшення потужності коливань у фронтальних ділянках кори: у $\delta$-діапазоні зони $\mathrm{F}_{7}, \mathrm{~F}_{8}$ та у $\theta$-діапазоні - зони $\mathrm{F}_{3}, \mathrm{~F}_{4}$ у студентів із більш розвиненими схильностями до логічних операцій (рис. 4).

Характер змін показників когерентності біопотениіалів кори головного мозку у процесі словесно-логічного мислення. У групи студентів із низьким рівнем прояву словесно-логічного мислення $\alpha$-хвилі у фронтальних центральних, скроневих i потиличних відведеннях мали високі когерентні зв'язки 3 іншими структурами кори тільки у парах $\mathrm{F}_{4}-\mathrm{F}_{7}, \mathrm{Fp}_{1}-\mathrm{P}_{3}$ ці зв'язки були більш поширеними (рис. 5). Спостерігався висо- кий ступінь зв'язку між фронтальними $\mathrm{Fp}_{1}$ та $\mathrm{Fp}_{2}, \mathrm{Fp}_{1}$ й $\mathrm{F}_{8} \mathrm{i}$ скроневим $\mathrm{T}_{5}$ відведеннями та деяка синхронність між фронтальними та скроневими, центральними та парієтальними зонами. Вважаємо, що в осіб із низькою продуктивністю логічного мислення нечисленні синхронні зв'язки пов'язані із психовегетативними проявами, які виникали як реакції на складні завдання, саме такі реакції спостерігали Machinskaja and Koshel'kov (2010) за психовегетативних і нервозних синдромів.

У студентів із середнім рівнем прояву словесно-логічного мислення посилюються функціональні зв'язки між фронтальними $\mathrm{Fp}_{1}-\mathrm{Fp}_{2}$ точками $(\mathrm{KК}=0,87)$. У передній частині півкуль установлено середні рівні коефіцієнта когерентності (KK) $\mathrm{F}_{4-}$ $\mathrm{F}_{3}, \mathrm{Fp}_{1}-\mathrm{F}_{7}, \mathrm{Fp}_{1}-\mathrm{F}_{8}, \mathrm{Fp}_{2}-\mathrm{F}_{7}, \mathrm{Fp}_{2}-\mathrm{F}_{8}$. Більшість значущих КК між фронтальними зонами $\mathrm{F}_{3}, \mathrm{~F}_{4}$ i центральними, тім'яними та скроневими ділянками обох півкуль. Щодо центральних структур мозку, то більш функціонально зв'язана з різними відділами кори точка $\mathrm{C}_{3}$, а активність в області $\mathrm{C}_{4}$ когерентна 3 тім'яною $\mathrm{P}_{4}$ та деякими фронтальними $\mathrm{F}_{3}, \mathrm{~F}_{4}, \mathrm{~F}_{7}, \mathrm{~F}_{8}$ та $\mathrm{T}_{4}$ скроневою зонами. Картина синхронної роботи тім'яних ділянок подібна у відведеннях $\mathrm{F}_{3}, \mathrm{~F}_{4}$ та має зв'язок у парі $\mathrm{F}_{4}-\mathrm{Fp}_{2}$. У відведенні $\mathrm{O}_{1}$ встановлені значимі зв'язки тільки з $\mathrm{C}_{3}, \mathrm{O}_{2}, \mathrm{~T}_{4}$ областями.

Отже, грунтуючись на отриманих даних, можна констатувати, що вищий прояв логічного мислення збільшує функціональний зв'язок $\alpha$-хвиль в області фронтальних і центральних частинах кори головного мозку.

У студентів із низьким рівнем логічного мислення кількість значущих функціональних зв'язків невелика, а високий ступінь когерентності (КК $\geq 8,0)$ СП спостерігався у $\beta_{1}$-діапазоні між фронтальними $\mathrm{Fp}_{2}-\mathrm{F}_{8}$, центральними та скроневими $\mathrm{C}_{4}-\mathrm{T}_{4}$ та 
скроневими $\mathrm{T}_{3}-\mathrm{T}_{5}$ відведеннями. Із розвитком здібності до словесно-логічного мислення залишаються значимими КК у $\beta_{1}$-діапазоні між фронтальними $\mathrm{F}_{3}-\mathrm{F}_{4}, \mathrm{~F}_{4}-\mathrm{C}_{4}$, центральними та тім'яними $\mathrm{C}_{3}-\mathrm{P}_{3}$, $\mathrm{C}_{4}-\mathrm{P}_{3}, \mathrm{C}_{4}-\mathrm{P}_{4}$, потиличними $\mathrm{O}_{1}-\mathrm{O}_{2}$ відведеннями, а також установлено достатньо високі функціональні зв'язки між $\mathrm{F}_{3}-\mathrm{T}_{6}, \mathrm{~F}_{3}-\mathrm{C}_{4}$ та $\mathrm{F}_{4}-\mathrm{P}_{3}, \mathrm{~F}_{7}-\mathrm{O}_{1}, \mathrm{~F}_{8}-\mathrm{O}_{1}, \mathrm{~T}_{3}-\mathrm{T}_{5}$ ділянками кори.
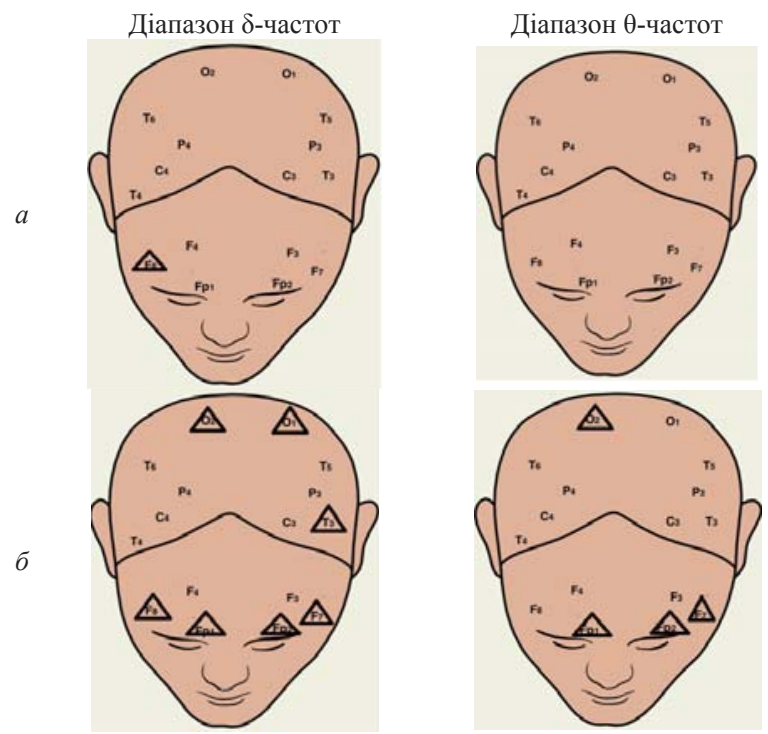

Рис. 3. Зміни показників потужності низькочастотних складових ЕЕГ у процесі інтуїтивного мислення у студентів із низьким (a) і середнім (б) проявом продуктивності мислення порівняно зі станом спокою із закритими очима; трикутник із вершиною донизу свідчить про зниження, з вершиною догори - про зростання СП частот $\delta, \theta$-діапазону за рівня значимості $\mathrm{P}<0,05$ за критерієм Вілкоксона

Загальна кількість когерентних зв'язків в осіб із середнім рівнем прояву логічного мислення більша, ніж у студентів із низькими показниками продуктивності. Отже, з розвитком логічного мислення найбільші зміни спектральної потужності $\beta$-ритму встановлені у фронтальному $\mathrm{F}_{7}$, скроневому $\mathrm{T}_{6}$ i центральних відведеннях. На підвищення $\beta$-ритмів у потиличних і лобних областях за активною розумовою діяльністю дітей із високими якостями когнітивної активності вказують автори (Dordzhieva and Pantina, 2015). Крім того, слід відмітити, що завдання були не складними для студентів, тобто їх виконання не викликало розвитку втоми, яка виражалась би у значному посиленні потужності $\beta$-ритму (Kiroj, 2003), а цього ми не спостерігали у жодного піддослідного.
Діапазон $\delta$-частот

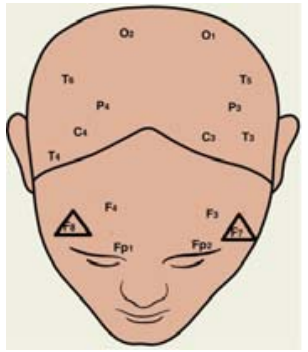

Діапазон $\theta$-частот

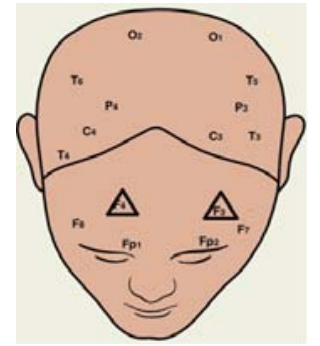

Рис. 4. Ділянки вірогідного зниження СП низькочастотних складових ЕЕГ у студентів із середнім рівнем прояву інтуїтивного мислення порівняно зі студентами з низькою продуктивністю за рівня значимості $\mathrm{P}<0,05$ за U-критерієм Манна - Уїтні; позначення див. рис. 3

У групи студентів із низьким рівнем прояву логічного мислення встановлено високу когерентність в $\beta_{2}$-діапазоні у передніх $\mathrm{Fp}_{2}-\mathrm{O}_{1}, \mathrm{~F}_{3}-\mathrm{C}_{3}, \mathrm{~F}_{3}-\mathrm{C}_{4}, \mathrm{~F}_{3}-\mathrm{T}_{4}$ та центральних $\mathrm{C}_{3}-\mathrm{T}_{6}$ відведеннях і високі міжпівкульні потиличні $\mathrm{O}_{1}-\mathrm{O}_{2}$ взаємодії. У студентів із середнім рівнем розвитку логічного мислення існує синхронізація між фронтальними $\mathrm{Fp}_{1}-\mathrm{Fp}_{2}, \mathrm{Fp}_{2}-\mathrm{F}_{7}$ та $\mathrm{F}_{3}-\mathrm{F}_{4}, \mathrm{C}_{3}-\mathrm{C}_{4}$, $\mathrm{O}_{1}-\mathrm{T}_{5}, \mathrm{~T}_{3}-\mathrm{T}_{4}$ відведеннями. Загальна кількість когерентних зв'язків у $\beta_{2}$-діапазоні осіб із середнім рівнем прояву логічного мислення більша, ніж у студентів із низькими показниками під час виконання завдань на логіку. $a$

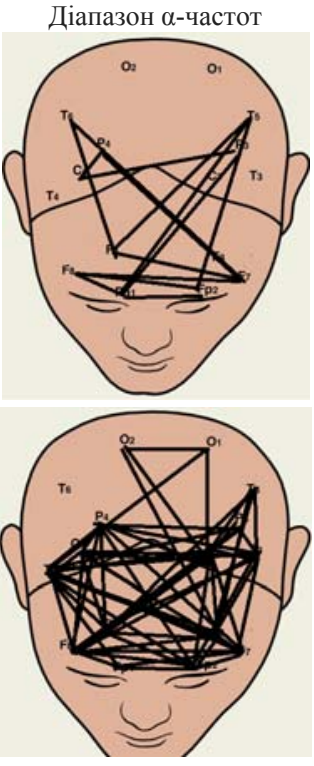

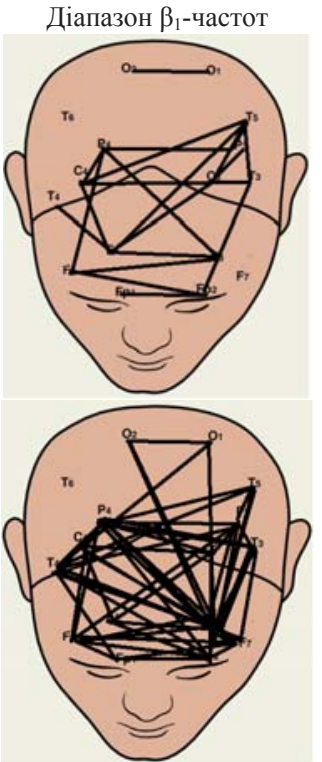

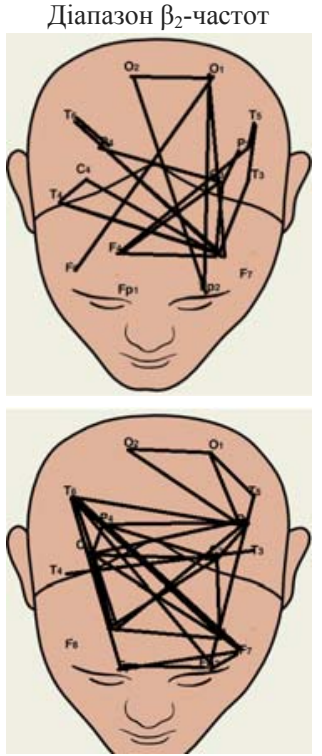

Рис. 5. Вірогідне збільшення $(\mathrm{P}<0,05)$ когерентності біопотенціалів $\alpha, \beta_{1}, \beta_{2}$-складових ЕЕГ під час наочно-образного мислення у студентів із низьким ( $a$ ) і середнім (б) проявом продуктивності мислення порівняно зі станом спокою із закритими очима

Аналізуючи літературні дані, можна відмітити деякі особливості когерентності під час виконання різних типів когнітивних завдань. Petsche and Etlinger (1998) показали, що зміни активності біопотенціалів та когерентності областей мозку у $\beta$-діапазоні реєструються під час виконання завдань на творче мислення та пов'язані з ефективністю їх виконання. Відміча- ють, що у більшості завдань показники когерентності більш індикативні, ніж характеристики потужності ритмів. Збільшення когерентності $\alpha, \beta, \Upsilon$-діапазонів під час виконання зоровомоторного завдання також зазначено у дослідженнях із застосуванням електродів, які накладались безпосередньо на кору мозку (Aoki et al., 2001). Також існують праці, в яких показано, що 
посилення когерентності не завжди корелює 3 успішністю виконання завдання. Автори (Deeny et al., 2003, 2009) припускають, що у разі автоматизації навички когерентність між зонами мозку знижується, отже, менша когерентність може відповідати більш успішній діяльності.
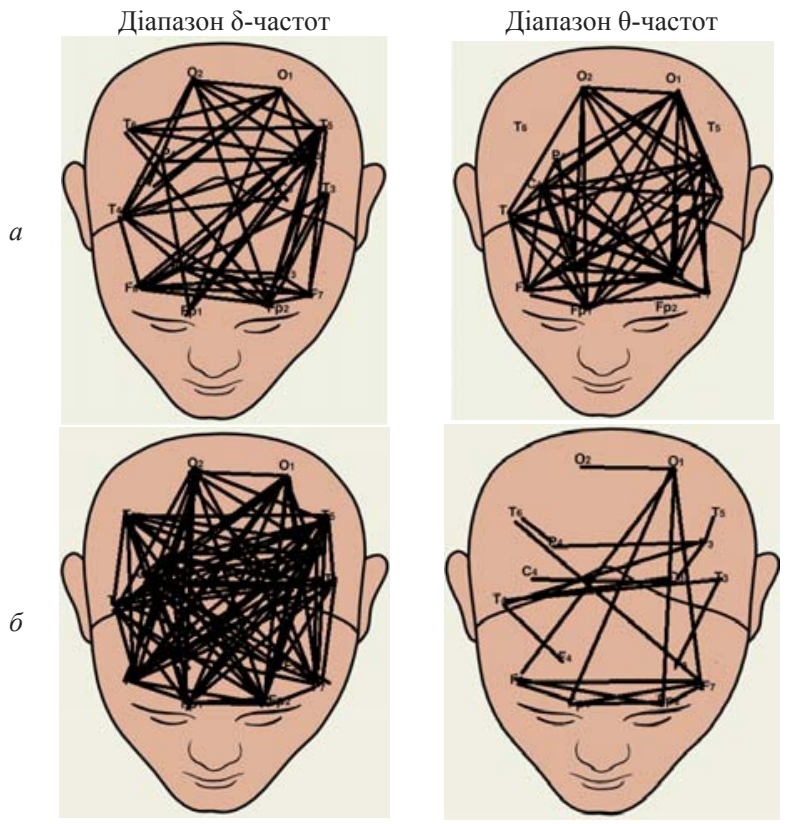

Рис. 6. Вірогідне збільшення $(\mathrm{P}<0,05)$ когерентності

біопотенціалів $\delta$-, $\theta$-складових ЕЕГ у процесі словеснологічного мислення у студентів із низьким (a) i середнім (б) проявом продуктивності мислення порівняно зі станом спокою із закритими очима

Під час виконання завдання на логіку у студентів 3 незначним проявом цього типу мислення встановлені функціональні зв'язки у $\delta$-діапазоні між багатьма структурами як передніх, так і задніх відділів кори головного мозку. В осіб із більш вираженими здібностями до словесно-логічного мислення збільшується як КК у $\delta$-діапазоні, так і загальна кількість когерентних зв'язків (рис. 6). Подібні результати отримані Zhavo- ronkova et al. (2011), які показали, що виконання когнітивних завдань супроводжується збільшенням когерентності повільних складових ЕЕГ ( $\delta$ - та $\theta$-діапазону) із включенням лівої півкулі та лобних областей кори.

Отже, оскільки природа зміни $\delta$-ритму донині остаточно не вивчена, згідно з традиційними поглядами, складна розумова активність супроводжується виникненням дифузного $\delta$-ритму, збільшенням його потужності (Rusinov, 1973). У дослідженні Dordzhieva and Pantina (2015) установлено домінування $\delta$ ритму як у стані неспання, так під час розумової активності незалежно від розумових здібностей у дітей.

У студентів із низькими результатами виконання тесту на словесно-логічне мислення встановлені високі когерентні залежності у $\theta$-діапазоні між фронтальними ділянками та іншими відділами $\mathrm{Fp}_{1}-\mathrm{C}_{4}, \mathrm{Fp}_{1}-\mathrm{P}_{3}, \mathrm{Fp}_{1}-\mathrm{O}_{1}, \mathrm{Fp}_{1}-\mathrm{T}_{4}, \mathrm{~F}_{3}-\mathrm{F}_{4}, \mathrm{~F}_{4}-\mathrm{C}_{4}$, $\mathrm{F}_{4}-\mathrm{P}_{3}, \mathrm{~F}_{4}-\mathrm{O}_{1}, \mathrm{~F}_{4}-\mathrm{T}_{4}, \mathrm{~F}_{8}-\mathrm{C}_{4}, \mathrm{~F}_{8}-\mathrm{P}_{3}$, центральними та скроневими $\mathrm{C}_{4}-\mathrm{T}_{4}$, потиличними та тім'яними та скроневими $\mathrm{P}_{3}-\mathrm{O}_{1}, \mathrm{O}_{1}-\mathrm{T}_{3}$, $\mathrm{O}_{1}-\mathrm{T}_{4}$, скроневими між собою $\mathrm{T}_{3}-\mathrm{T}_{4}$. Із розвитком словеснологічного способу мислення головний мозок переходить в особливий режим функціонування 3 низьким функціональним зв'язком в області $\theta$-осциляцій.

Синхронізація біоелектричної активності в області $\theta$-ритму збільшується під час виконання завдань, які вимагають утримання інформації у робочій пам'яті (Sarnthein et al., 1998; Tesche and Karhu, 2000). Отримані дані дозволяють розглядати збільшення ступеня функціональної взаємодії коркових зон на основі $\theta$-ритмів як показник сформованої стратегії та залучення лімбічних структур у реалізацію когнітивних процесів (Bernat et al., 2008). Результати нашого дослідження також дозволяють припустити, що специфічна роль фронтальних полюсних і центральних зон забезпечується їх взаємодією на основі синхронізації $\theta$-ритму 3 іншими корковими та глибинними структурами мозку. Це можуть бути лімбічні структури, робота яких пов'язана 3 утриманням уваги, самоконтролем, оцінюванням результатів своєї діяльності (Posner et al., 2007), а також структури, які відповідають за утримання інформації пам'яті - гіпокамп, тім'яна кора, специфічні коркові зони. Таким чином, виявлені особливості топографії функціональних зв'язків під час виконання когнітивних завдань: локалізація фокусів взаємодії на $\alpha$ - та $\beta$-частотах у лобних полюсних ділянках та інтеграція цих фронтальних зон з іншими ділянками кори, що повністю збігається з висновками (Segalowitz and Dywan, 2009).

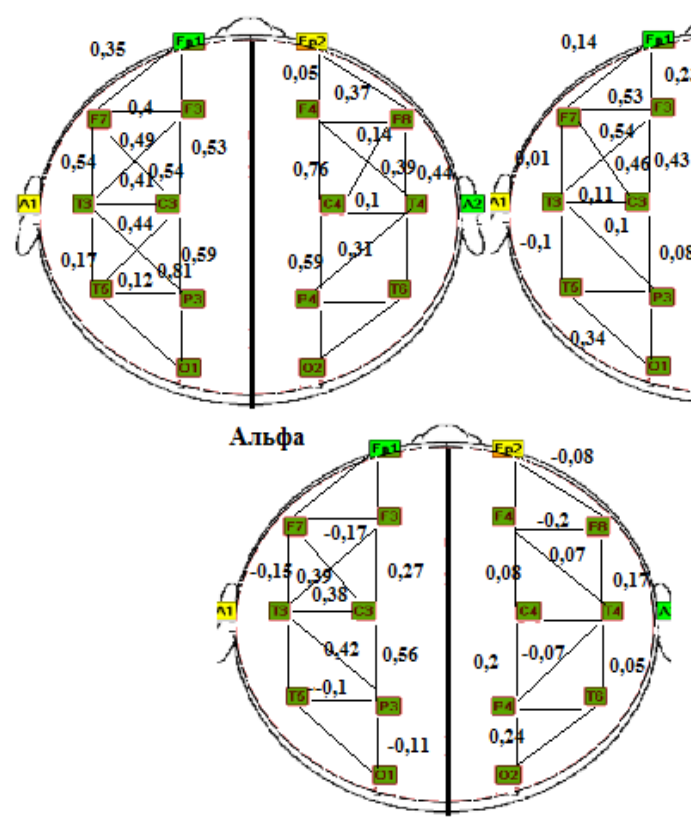

Дельта
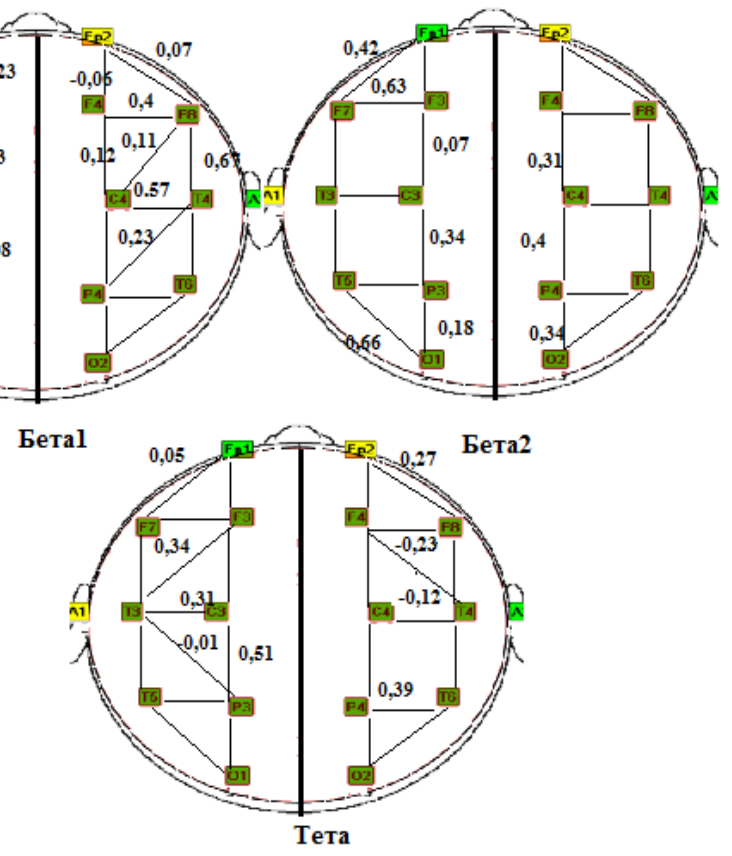

Рис. 7. Карти різниці вірогідних змін когерентності внутрішньокульових складових ЕЕГ у студентів із різним проявом словесно-логічного мислення 
Із розвитком здатності до логічного мислення встановлено найбільшу кількість значимих коефіцієнтів когерентності на $\delta$-частоті, оскільки саме вона формує вхідний сенсорний потік, це «спеціальні частоти» сприйняття, пов'язані з селективною увагою (Schroeder and Lakatos, 2009) та у $\beta_{1}$-діапазоні, що може бути як ознакою високого рівня IQ студентів-біологів, так і ознакою когнітивного контролю (Engel and Fries, 2010) та реакцією на нові сигнали (у нашому випадку незнайомі слова). Незначна кількість кореляцій у $\beta_{2}$-діапазоні свідчить про зниження синхронізації між віддаленими нейронними ансамблями (Kukleta et al., 2009). У цьому частотному діапазоні більше синхронізована активація фронтальної, центральної, тім'яної та потиличної зоні лівої півкулі, а також фронтальної, центральної та тім'яної частин правої півкулі, що забезпечило комплексний логіко-семантичний аналіз вербальної інформації, аналіз сенсу речень і слів із залученням асоціативної кори (рис. 7).

Для лобної зони лівої півкулі характерна синхронізація активності у $\beta$-частотному діапазоні, що збігається з результатами дослідження Thatcher et al. (2005), в яких показано, що рівень інтелекту корелює зі складністю організації мозку та синхронізацією активності в лобній зоні вищого рівня активності мозку у $\delta$-діапазоні (Tongran et al., 2008). У студентів із кращим проявом логічного мислення встановлені найнижчі рівні функціонального зв'язку у $\theta$-діапазоні. Взагалі активність у цьому ЕЕГ-інтервалі пов'язують із координацією міжрегіональних взаємодій під час виконання поставлених завдань і контролем за помилковістю відповідей (Bernat et al., 2008), отже, відсутність значущих змін у $\theta$-діапазоні свідчить про збереження попередньо сформованої нейромежі, тобто словесно-логічні тести виконуються в рамках єдиної нейромережі. У праці Kupa and Filimonova (2014) під час обговорення власних результатів дослідження використано аргумент (Sauseng and Klimesch, 2008), що нейромережі різного розміру припускають осциляції різних частот: більші генерують нижчі частоти, що можна привести на користь припущення про певне звуження нейромережі, яка здійснює координацію між зонами Брока та Posterior cingulate cortex. За підвищення здатності до успішного виконання словесно-логічних завдань збільшується кількість значущих КК в $\alpha$-діапазоні у лівій фронтальній зоні (рис. 7). Це можна пояснити пошуком спільних рис тверджень у ділянках поблизу зони Верніке, що пов'язано з активізацією специфічних процесів семантичного аналізу та визначенням сенсу слів та збільшенням кількості значущих коефіцієнтів когерентності у контурній області $\mathrm{F}_{4}-\mathrm{F}_{8}$ $\mathrm{T}_{4}-\mathrm{P}_{4}$ правої півкулі, що, у свою чергу, пов'язано 3 образним уявленням слів у правій асоціативній корі.

Незважаючи на значний прогрес у розумінні окремих моментів функціонування мозку у процесі когнітивної діяльності, ще не існує чіткого розуміння зв'язку окремих ритмів та їх взаємодії з успішністю інтелектуальної діяльності. Успішність виконання завдання пов'язують як зі збільшенням когерентності або потужності різних ритмів ЕЕГ, так і зі зниженням. Таким чином, результати різних досліджень мають досить суперечливий характер і залежать від конкретного типу завдань, а також умов діяльності, що не дозволяє виділити чіткі кореляти успішності когнітивної діяльності (Karatygin, 2015). Але, незважаючи на всю складність питання дослідження механізмів вищих психічних функцій мислення, у будь-якому випадку простежується залежність між типом завдання, стратегією виконання поставленого завдання та мозковими коррелятами.

\section{Висновки}

Під час виконання словесно-логічних завдань у студентів iз більш розвиненим типом когнітивного мислення збільшується кількість значущих коефіцієнтів когерентності в $\alpha$-діапазоні, як у лівій фронтальній зоні та у ділянках поблизу зони Верніке, а також у контурній області $\mathrm{F}_{4}-\mathrm{F}_{8}-\mathrm{T}_{4}-\mathrm{P}_{4}$ правої півкулі, що пов'язано 3 пошуком спільних рис оцінювання тверджень, активізацією специфічних процесів аналізу, визначенням сенсу слів і образним уявленням у процесі мислення.
У студентів із середнім рівнем словесно-логічного мислення під час виконання завдань зафіксовано значну кількість значущих функціональних зв'язків та високі значення коефіцієнтів когерентності між фронтальними $\mathrm{F}_{3}-\mathrm{F}_{4}, \mathrm{~F}_{4}-\mathrm{C}_{4}$, центральними та тім'яними $\mathrm{C}_{3}-\mathrm{P}_{3}, \mathrm{C}_{4}-\mathrm{P}_{3}, \mathrm{C}_{4}-\mathrm{P}_{4}$ i потиличними $\mathrm{O}_{1}-\mathrm{O}_{2}$ відведеннями у $\beta_{1}$-діапазоні, що може бути як ознакою високого рівня інтелекту студентів-біологів, так і результатом когнітивного контролю або реакцією на незнайомі слова.

Загальна кількість когерентних зв'язків у $\beta_{2}$-діапазоні студентів із середнім рівнем прояву логічного мислення більша, ніж у студентів із низькими показниками під час виконання завдань на логічне мислення. Також існує синхронізація СП $\beta_{2}$-діапазону між передніми $\mathrm{Fp}_{1}-\mathrm{Fp}_{2}, \mathrm{Fp}_{2}-\mathrm{F}_{7}, \mathrm{~F}_{3}-\mathrm{F}_{4}$ та іншими $\mathrm{C}_{3}-\mathrm{C}_{4}, \mathrm{O}_{1}-\mathrm{T}_{5}, \mathrm{~T}_{3}-\mathrm{T}_{4}$ відведеннями.

Із розвитком здатності до когнітивного мислення збільшується кількість когерентних зв'язків СП ЕЕГ в області $\delta$ діапазону, оскільки саме вони формують вхідний сенсорний потік і пов'язані із селективною увагою.

Із розвитком словесно-логічного способу мислення головний мозок переходить в особливий режим функціонування 3 низьким функціональним зв'язком в області $\theta$-осциляцій, що свідчить про збереження попередньо сформованої нейромережі.

\section{References}

Angelakis, E., Lubar, J., Stathopoulou, S., \& Kounios, J. (2004). Peak alpha frequency: An electroencephalographic measure of cognitive preparedness. Clinical Neurophysiology, 115, 887-897.

Aoki, F., Fetz, E. E., Shupe, L., Lettich, E., \& Ojemann, G. A. (2001). Changes in power and coherence of brain activity in human sensorimotor cortex during performance of visuomotor tasks. Biosystems, 63(1-3), 89-99.

Bernat, E., Lindsay, D., Holroyd, B., \& Gehring, W. (2008). Separating cognitive processes with principal components analysis of EEG timefrequency distributions. Proceedings of SPIE - The International Society for Optical Engineering, 7074, 326-333.

Bidelman, G. M., \& Howell, M. (2016). Functional changes in inter- and intra-hemispheric auditory cortical processing underlying degraded speech perception. Neuroimage, 124, 581-590.

Cohen, M. X., Elger, C. E., \& Ranganath, C. (2007). Reward expectation modulates feedback-related negativity and EEG spectra. Neuroimage, 35(2), 968-978.

Crick, F., \& Koch, C. (1995). Are we aware of neural activity in primary visual cortex? Nature, 375, 121-123.

Deeny, S. P., Haufler, A. J., Saffer, M., \& Hatfield, B. D. (2010). Electroencephalographic coherence during visuomotor performance: A comparison of cortico-cortical communication in experts and novices. Journal of Motor Behavior, 41(2), 106-116.

Deeny, S. P., Hillman, C. H., Janelle, C. M., \& Hatfield, B. D. (2003). Cortico-cortical communication and superior performance in skilled marksmen: An EEG coherence analysis. Journal of Sport and Exercise Psychology, 25(2), 188-204.

Dordzhieva, D. B., \& Pantina, E. E. (2015). Biojelektricheskaja aktivnost' golovnogo mozga individov s razlichnym urovnem myslitel'noj dejatel'nosti [Bioelectrical activity of the brain of individuals with different levels of mental activity]. Estestvennye i Matematicheskie Nauki v Sovremennom Mire, 4, 28 (in Russian).

Dzhebrailova, T. D., \& Korobejnikova, I. I. (2013). Prostranstvennaja organizacija beta2-ritma EEG i effektivnosti kognitivnoj dejatelnosti cheloveka [Spatial organization of the EEG beta2-rhythm and the effectiveness of human cognitive activity]. I. P. Pavlov Journal of Higher Nervous Activity, 63(6), 667-676 (in Russian).

Dzhebrailova, T. D., Korobeinikova, I. I., Dudnik, E. N., \& Karatygin, N. A. (2015). Spatial organization of alpha range potentials on EEG and logical thinking effectiveness. Bulletin of Experimental Biology and Medicine, 159(2), 184-187.

Dzhebrailova, T. D., Korobeinikova, I. I., Dudnik, E. N., \& Karatygin, N. A. (2017). Vzaimosvyaz' parametrov teta i beta-aktivnosti EEG i variabel'nosti serdechnogo ritma pri intellektual'noy deyatel'nosti cheloveka [Interrelation between theta and beta activity parameters of the EEG and heart rate variability in human intellectual activity]. Human Physiology, 43(2), 91-105 (in Russian).

Dzhebrailova, T. D., Korobejnikova, I. I., \& Karatygin, N. A. (2013). Kogerentnost' potencialov $\beta 1$ diapazona EEG i effektivnost' intelektualnej deyatelnosti cheloveka [EEG coherence in the $\beta 1$ frequency band and efficiency of human intellectual activity]. Journal of New Medical Technologies, 20(3), 71-74 (in Russian). 
Engel, A. K., \& Fries, P. (2010). Beta-band oscillations-signalling the status quo? Current Opinion in Neurobiology, 20(2), 156-165.

Fink, A., Hauswirth, V., Fally, M., Neuper, C., Neubauer, A. C., Grabner, R. H., Benedek, M., Reishofer, G., \& Ebner, F. (2009). The creative brain: Investigation of brain activity during creative problem solving by means of EEG and FMRI. Human Brain Mapping, 30(3), 734-748.

Freeman, W. J., \& Barrie, J. M. (2000). Analysis of spatial patterns of phase in neocortical gamma EEGs in rabbit. Journal of Neurophysiology, 84(3), 1266-1278.

Freunbergera, R., Werkle-Bergnera, M., Griesmayrb, B., Lindenbergera, U., \& Klimeschb, W. (2011). Brain oscillatory correlates of working memory constraints. Brain Research, 1375, 93-102.

Gross, D. W., \& Gotman, J. (2009). Correlation of high-frequency oscillations with theslep-wake cycle and cognitive activity in humans. Neuroscience, 94(4), 1005-1018.

Hyunjeong, L. (2013). The effect of film as the virtual context on logical thinking of engineering students. Journal of Engineering Education Research, 16, 3-10.

Ivanitsky, G. A., Naumov, R. A., \& Roik, A. O. (2010). EEG portrait of a person: characteristic patterns of brain rhythms under cognitive load of certain types. International Journal of Psychophysiology, 77(3), 314.

James, N. (2012). Logical, critical and creative: teaching 'thinking skills' to law students. Queensland University of Technology Law and Justice Journal, 12(1), 66-88.

Jashin, B. L. (2015). Racional'nost' i logicheskoe myshlenie [Rationality and logical thinking]. Filosofskaja Mysl', 10, 75-87 (in Russian).

Kiroj, V. N. (2003). Fiziologicheskie metody v psihologii [Physiological methods in psychology]. CVVR, Rostov-na-Donu (in Russian).

Kiselev, A. R., Gridnev, V. I., Posnenkova, O. M., Strunina, A. N., Shvarts, V. A., \& Dovgalevskii, Y. P. (2008). Changes in the power of the low- and highfrequency bands of the heart rate variability spectrum in coronary heart disease patients with different severities of coronary atherosclerosis in the course of load tests. Human Physiology, 34(3), 312-318.

Klawitter, K., Öllinger, M., Faber, A., Filk, T., Timmer, J., \& Schelter, B. (2010). Analysis of EEG data on complex human thinking. Clinical Neurophysiology, 41(1), 101.

Klimesch, W. (1997). EEG-alpha rhythm sand memory processes. International Journal of Psychophysiology, 26(1-3), 319-340.

Klimesch, W. (1999). EEG alpha and theta oscillations reflect cognitive and memory performance: A review and analysis. Brain Research Reviews, 29, 169-195.

Klimesch, W., Freunberger, R., \& Sauseng, P. (2010). Oscillatory mechanisms of process binding in memory. Neuroscience and Biobehavioral Reviews, 34(7), 1002-1014.

Korobeinikova, I. (2016). Spektral'nye harakteristiki teta ritma JeJeG i jeffektivnost' intellektual'noj dejatel'nosti [Spectral EEG indicators of theta-rythm and efficiency of intellectual activity]. Tjumenskij Medicinskij Zhurnal, 18(2), 50-55 (in Russian).

Koshelkov, D. A., \& Machinskaya, R. I. (2010). Functional coupling of cortical areas during problem-solving task: Analysis of $\theta$-rhythm coherence. Human Physiology, 36(6), 665-669.

Kraft, E., Poeppel, E., \& Gulyas, B. (2009). Neural correlates of thinking. Springer, Heidelberg.

Kukleta, M., Brázdil, M., Roman, R., Bob, P., \& Rektor, I. (2009). Cognitive Network interactions and beta- 2 coherence in processing non-target stimuli in visual oddball task. Physiological Research, 58, 139-148.

Kupa, L. V., \& Filimonova, N. B. (2014). Zminy aktyvnosti golovnogo mozku cholovikiv pry vykonannja verbal'nyh subtestiv logichnogo vidboru ta vyznachennja zagal'nyh rys testu Amthauera [Changes of activity of cerebrum of men in performance of verbal subtests of logical selection and determination of general features of Amthauer test]. Bulletin of Cherkasy University, 295, 64-69 (in Ukrainian).

Limbach, K., \& Corballis, P. M. (2017). Alpha-power modulation reflects the balancing of task requirements in a selective attention task. Psychophysiology, 54(2), 224-234.

Makeig, S., \& Jung, T. (1996). Tonic, phasic, and transient EEG correlates of auditory awareness in drowsiness. Cognitive Brain Research, 4(1), 15-25.

Payne, B. R., \& Peters, A. (2002). The cat primary visual cortex. Academic Press, San Diego.
Petsche, H., \& Etlinger, S. C. (1998). EEG aspects of cognitive processes: A conribution to the proteus-like nature of consciousness. International Journal of Psychophysiology, 33(3), 199-212.

Poch, C., Campo, P., \& Barnes, G. R. (2014). Modulation of alpha and gamma oscillations related to retrospectively orienting attention within working memory. European Journal of Neuroscience, 40(2), 2399-2405.

Posada, A., Franck, N., Vianin, P., Hugues, E., \& Kilner, J. (2003). Augmentation of induced visual gamma activity by increased task complexity. European Journal of Neuroscience, 18(8), 2351-2356.

Posner, M. I., Sheese, B., Rothbart, M., \& Tang, Y. Y. (2007). The anterior cingulate gyrus and the mechanism of self-regulation. Cognitive, Affective, and Behavioral Neuroscience, 7(4), 391-395.

Rappelsberger, P., Sarnthein, J., von Stein, A., \& Petsche, H. (1999). Synchronization between temporal and parietal cortex during multimodal object processing in man. Cerebral Cortex, 9(2), 137-150.

Roik, A. O., \& Ivanitsky, G. A. (2010). Patterns of brain rhythms while performing cognitive tasks with gradually changing properties. International Journal of Psychophysiology, 77, 314.

Rusinov, V. S. (1973). Klinicheskaja elektroencefalografija [Clinical electroencephalography]. Medicina, Moscow (in Russian).

Sarnthein, J., Petsche, H., Rappelsberger, P., Shaw, G. L., \& von Stein, A. (1998). Synchronization between prefrontal and posterior association cortex during human working memory. Proceedings of the National Academy of Sciences. 95(12), 7092-7096.

Sauseng, P., \& Klimesch, W. (2008). What does phase information of oscillatory brain activity tell us about cognitive processes? Neuroscience and Biobehavioral Reviews, 32(5), 1001-1013.

Sauseng, P., Conci, M., Wild, B., \& Geyer, T. (2015). Predictive coding in visual search as revealed by cross-frequency EEG phase synchronization. Frontiers in Psychology, 6, 1-5.

Schroeder, C. E., \& Lakatos, P. (2009). Low-frequency neuronal oscillations as instruments of sensory selection. Trends in Neurosciences, 32(1), 9-18.

Segalowitz, S. J., \& Dywan, J. (2009). Individual differences and developmental change in the ERN response: Implications for models of ACC function. Psychological Research, 73(6), 857-870.

Simos, P. G., Papanikolaou, E., Sakkalis, E., \& Micheloyannis, S. (2002). Modulation of gamma-band spectral power by cognitive task complexity. Brain Topography, 14(3), 191-196.

Slavutskaya, E. V. (2015). Slovesno-logicheskoe myshlenie i strukturirovanie lichnostnyh chert v predpodrostkovom vozraste [Verbal-logical thinking and the structuring of the preadolescents personality traits]. Izvestiya of Saratov University. New Series. Series: Educational Acmeology. Developmental Psychology, 4(3), 203-207 (in Russian).

Sviderskaya, N. E. (2011). The EEG spatial pattern and psychophysiological characteristics of divergent and convergent thinking in humans. Human Physiology, 37(1), 31-38.

Tesche, C. D., \& Karhu, J. (2000). Theta oscillations index human hippocampal activation during a working memory task. Proceedings of the National Academy of Sciences, 97(2), 919-924.

Thatcher, R. W., North, D., \& Biver, C. (2005). EEG and intelligence: Relations between EEG coherence, EEG phase delay and power. Clinical Neurophysiology, 116, 2129-2141.

Thürer, B., Stockinger, C., Focke, A., Putze, F., Schultz, T., \& Stein, T. (2016). Increased gamma band power during movement planning coincides with motor memory retrieval. NeuroImage, 125, 172-181.

Tongran, L., Jiannong, S., Daheng, Z., \& Jie, Y. (2008). The relationship between EEG band power, cognitive processing and intelligence in school-age children. Psychology Science Quarterly, 50(2), 259-268.

Trofimov, A. G., Ivanitskiy, I. I., \& Velichkovskiy, B. M. (2015). Klassifikacija signalov EEG s ispol'zovaniem "zhadnogo" algoritma postroenija komiteta klassifikatorov [Classification of EEG signals using a "greedy" algorithm for constructing a committee of weak classifiers]. Vestnik Natsional'nogo Issledovatel'skogo Yadernogo Universiteta MIFI, 4(6), 537-544 (in Russian).

Volf, N. V., \& Tarasova, I. V. (2010). The relationships between EEG $\Theta$ and $\beta$ oscillations and the level of creativity. Human Physiology, 36(2), 132-138.

Zhavoronkova, L. A., Kuptsova, S. B., Zharikova, A. V., Kushnir, E. M., \& Mikhalkova, A. A. (2011). Characteristics of EEG reactivity changes during the performance of dual tasks in healthy subjects (voluntary postural control and calculation). Human Physiology, 37(6), 688-699. 